\title{
Faktor - Faktor yang mempengaruhi Bioavailabilitas Besi bagi Tumbuhan
}

Gebhardus Djugian Gelyaman ${ }^{\mathrm{a}}$

${ }^{a}$ Kimia, Universitas Timor, Kefamenanu, TTU - NTT, Indonesia, email: dgelyaman@gmail.com

\section{Article Info}

\section{Article history:}

Received 20 Mei 2018

Received in revised form 30 Juni 2018 Accepted 15 Juli 2018

DOI:

https://doi.org/10.32938/slk.v1i1.439

\section{Keywords:}

Bioavailabilitas

Besi

Tumbuhan

Faktor-faktor

Pengaruh

\section{Pendahuluan}

Besi bagi tumbuhan berperan sebagai salah satu unsur hara mikro yang sangat penting selain $\mathrm{Cu}, \mathrm{Zn}, \mathrm{Mn}, \mathrm{Ni}$, Mo (Hänsch \& Mendel, 2009). Mikronutrisi ini tidak dibutuhkan dalam jumlah banyak oleh tumbuhan dibandingkan hara makro misalnya $\mathrm{C}, \mathrm{H}, \mathrm{O}, \mathrm{P}, \mathrm{N}, \mathrm{S}, \mathrm{Ca}, \mathrm{Mg}, \mathrm{K}$. Besi yang ditemukan sebanyak $0,01 \%$ dari berat kering jaringan tumbuhan, lebih kecil daripada unsur hara makro yaitu $\geq 0,1 \%$ massa kering jaringan tersebut (Seran, 2017). Namun, besi merupakan unsur esensial yang kehadirannya mutlak harus dipenuhi dalam metabolisme tumbuhan. Hara mikro ini dibutuhkan dalam proses respirasi, fotosintesis, sintesis DNA, sebagai penyusun sitokrom, perawat dan pengarah struktur kloroplas guna membentuk klorofil serta pengaktifan enzim (Rout \& Sahoo, 2015)

Keberadaan besi sangat melimpah di alam, namun pada daerah tertentu ketersediaan secara hayati atau bioavailabilitas besi bagi tumbuhan sangat rendah. Hal ini terjadi karena besi bersenyawa dengan unsur lain membentuk material sukar larut dalam air, sedangkan tanaman dapat menyerap besi dari dalam tanah hanya jika besi berada dalam bentuk solut. Akibatnya, tanaman akan mengalami defisiensi besi atau klorosis. Ciri - ciri klorosis pada tanaman adalah muncul bercak kuning pada daun muda, tanaman menjadi kerdil dan mati (Brown, 1956).

Kelarutan besi dalam air dipengaruhi oleh tingkat keasaman atau $\mathrm{pH}$ air tersebut. Hal serupa akan terjadi jika besi berada di dalam tanah yang memiliki $\mathrm{pH}$ yang bervariasi. Namun, selain $\mathrm{pH}$, terdapat faktor lain di alam yang juga mempengaruhi kelarutan besi seperti senyawa organik tanah, bakteri dan lainnya. Hingga saat ini, terdapat banyak penelitian terkait penanganan defisiensi besi bagi tumbuhan, Namun, sangat sedikit artikel yang merangkum secara rinci dan komprehensif terkait bioavailabilitas besi bagi tumbuhan. Oleh karena itu, artikel ini akan menyajikan hasil review terkait faktor - faktor yang mempengaruhi bioavailabilitas besi bagi tumbuhan meliputi pengaruh $\mathrm{pH}$, material organik tanah, bakteri dan reaksi redoks lingkungan.

\section{Sifat Fisika, Kimia dan Bentuk - Bentuk Mineral Besi di Alam}

Kajian terkait sifat fisika, kimia dan bentuk-bentuk mineral besi perlu diketahui sehingga diperoleh informasi terkait persenyawaan besi dan bentuknya dalam berbagai kondisi lingkungan.

\subsection{Sifat fisika}

Besi dalam keadaan murni berbentuk logam yang berwarna putih keabuabuan, mengkilat, keras dan dapat dibentuk dengan mudah (Vogel \& Svehla 1987). Besi pada temperatur ruang berada dalam bentuk ferrit atau disebut besi $\alpha$ yaitu besi dengan struktur body-centered cubic atau kubus terpusat badan, dengan kerapatan $7,87 \mathrm{~g} / \mathrm{cm}^{3}$. Besi adalah pengantar panas dan listrik yang baik. Konduktifitas panas besi adalah 3,37 $\mathrm{cal} \mathrm{s}^{-1} \mathrm{~cm}^{-1} \mathrm{~K}^{-1}$ dan kapasitas panas molar adalah $25,1 \mathrm{~J} \mathrm{~mol}^{-1} \mathrm{~K}^{-1}$. Besi $\alpha$ dapat berubah menjadi besi $\gamma$ yaitu besi dengan struktur kubik terpusat muka atau face-centered cubic jika temperatur ditingkatkan menjadi $910{ }^{\circ} \mathrm{C}$. Besi melebur pada $1535{ }^{\circ} \mathrm{C}$ dan mendidih pada suhu $3000{ }^{\circ} \mathrm{C}$ (Calvert, 2003).

\subsection{Sifat kimia}

Besi secara kimia memiliki massa atom relatif 56 gram $/ \mathrm{mol}$ dan nomor atom 26 dengan simbol Fe yang disingkat dari akar kata bahasa latin yaitu Ferrum. Besi dikelompokan ke dalam golongan unsur transisi dan termasuk golongan 8 blok d pada sistem tabel periodik unsur, dengan konfigurasi elektron [Ar] $3 \mathrm{~d}^{6}$ $4 s^{2}$. Besi memiliki beberapa tingkat oksidasi, namun yang paling umum adalah besi(II) dan besi(III). Besi(II) sangat reaktif dan memiliki kecenderungan teroksidasi menjadi besi(III) jika terkena udara. Beberapa reaksi kimia dari besi di antaranya :

a. Reaksi besi murni dengan air dapat menghasilkan besi(II) atau besi(III) hidroksida dan gas $\mathrm{H}_{2}$.

$$
\begin{aligned}
\mathrm{Fe}_{(\mathrm{s})}+2 \mathrm{H}_{2} \mathrm{O}_{(\mathrm{l})} & \longrightarrow \mathrm{Fe}(\mathrm{OH})_{2(\mathrm{~s})}+\mathrm{H}_{2(\mathrm{~g})} \\
2 \mathrm{Fe}_{(\mathrm{s})}+6 \mathrm{H}_{2} \mathrm{O}_{(\mathrm{l})} & \longrightarrow 2 \mathrm{Fe}(\mathrm{OH})_{3(\mathrm{~s})}+3 \mathrm{H}_{2(\mathrm{~g})}
\end{aligned}
$$

b. Reaksi garam besi dengan air pada $\mathrm{pH}$ netral menghasilkan ion besi.
$\mathrm{FeCl}_{2(\mathrm{~s})}+\mathrm{H}_{2} \mathrm{O}_{(\mathrm{l})} \longrightarrow \mathrm{Fe}^{2+}{ }_{(\mathrm{aq})}+2 \mathrm{Cl}_{(\mathrm{aq})}^{-}$

$\mathrm{FeCl}_{3(\mathrm{~s})}+\mathrm{H}_{2} \mathrm{O}_{(\mathrm{l})} \longrightarrow \mathrm{Fe}^{3+}{ }_{(\mathrm{aq})}+3 \mathrm{Cl}^{-}(\mathrm{aq})$

$\mathrm{FeSO}_{4(\mathrm{~s})}+\mathrm{H}_{2} \mathrm{O}_{(\mathrm{l})} \longrightarrow \mathrm{Fe}^{2+}{ }_{(\mathrm{aq})}+\mathrm{SO}_{4}{ }^{2-}{ }_{(\mathrm{aq})}$

$\mathrm{Fe}_{2}\left(\mathrm{SO}_{4}\right)_{3(\mathrm{~s})}+\mathrm{H}_{2} \mathrm{O}_{(\mathrm{l})} \longrightarrow 2 \mathrm{Fe}^{3+}{ }_{(\mathrm{aq})}+3 \mathrm{SO}_{4}{ }^{2-}$

c. Reaksi besi murni dengan asam

Reaksi dengan asam klorida menghasilkan gas hidrogen

$$
\mathrm{Fe}_{(\mathrm{s})}+2 \mathrm{HCl}_{(\mathrm{aq})} \longrightarrow \mathrm{Fe}^{2+}{ }_{(\mathrm{aq})}+2 \mathrm{Cl}_{(\mathrm{aq})}^{-}+\mathrm{H}_{2(\mathrm{~g})}
$$

pada asam sulfat pekat panas menghasilkan besi(III) dan belerang dioksida $2 \mathrm{Fe}_{(\mathrm{s})}+3 \mathrm{H}_{2} \mathrm{SO}_{4(\mathrm{aq})}+6 \mathrm{H}^{+}{ }_{(\mathrm{aq})} \longrightarrow 2 \mathrm{Fe}^{3+}{ }_{(\mathrm{aq})}+3 \mathrm{SO}_{2(\mathrm{~g})}+6 \mathrm{H}_{2} \mathrm{O}_{(\mathrm{l})}$

pada asam nitrat encer dingin menghasilkan besi(II) dan ammonia,

$4 \mathrm{Fe}_{(\mathrm{s})}+10 \mathrm{H}^{+}{ }_{(\mathrm{aq})}+\mathrm{NO}_{3}{ }_{(\text {(aq })} \longrightarrow 4 \mathrm{Fe}^{2+}{ }_{(\mathrm{aq})}+\mathrm{NH}_{4}{ }^{2+}{ }_{(\mathrm{aq})}+3 \mathrm{H}_{2} \mathrm{O}_{(1)}$

pada asam nitrat pekat panas menghasilkan gas $\mathrm{NO}$ dan besi(III).

$\mathrm{Fe}_{(\mathrm{s})}+\mathrm{HNO}_{3(\mathrm{aq})}+3 \mathrm{H}^{+}{ }_{(\mathrm{aq})} \longrightarrow \mathrm{Fe}^{3+}{ }_{(\mathrm{aq})}+\mathrm{NO}_{(\mathrm{g})}+3 \mathrm{H}_{2} \mathrm{O}_{(\mathrm{l})}$

d. Reaksi dengan basa

Reaksi dalam larutan $\mathrm{NaOH}$

Besi(II) bereaksi dengan basa menghasilkan endapan putih $\mathrm{Fe}(\mathrm{OH})_{2}$ dan

jika terpapar oleh udara, endapan ini akan teroksidasi menjadi besi(III)

hidroksida berwarna coklat kemerahan

$\mathrm{Fe}^{2+}{ }_{(\mathrm{aq})}+2 \mathrm{OH}^{-}{ }_{(\mathrm{aq})} \longrightarrow \mathrm{Fe}(\mathrm{OH})_{2(\mathrm{~s})}$

$4 \mathrm{Fe}(\mathrm{OH})_{2(\mathrm{~s})}+2 \mathrm{H}_{2} \mathrm{O}_{(\mathrm{l})}+\mathrm{O}_{2(\mathrm{~g})} \longrightarrow 4 \mathrm{Fe}(\mathrm{OH})_{3(\mathrm{~s})}$

Besi (III) bereaksi dengan basa menghasilkan besi(III) hidroksida $\mathrm{Fe}^{3+}{ }_{(\mathrm{aq})}+3 \mathrm{OH}_{(\mathrm{aq})}^{-} \longrightarrow \mathrm{Fe}(\mathrm{OH})_{3(\mathrm{~s})}$

Reaksi dalam larutan $\mathrm{NH}_{4} \mathrm{OH}$

Besi(II) bereaksi dengan amonium hidroksida menghasilkan endapan putih ni akan larut lagi jika konsentrasi ammonia berlebih

$$
\mathrm{Fe}^{2+}{ }_{(\mathrm{aq})}+\mathrm{NH}_{4} \mathrm{OH}_{(\mathrm{aq})} \longrightarrow \mathrm{Fe}(\mathrm{OH})_{2(\mathrm{~s})}+\mathrm{NH}_{4}{ }_{(\mathrm{aq})}
$$

Besi(III) bereaksi dengan amonium hidroksida menghasilkan endapan merah bata dan akan larut dengan amonium hidroksida berlebih $\mathrm{Fe}^{3+}{ }_{(\mathrm{aq})}+3 \mathrm{NH}_{4} \mathrm{OH}_{(\mathrm{aq})} \longrightarrow \mathrm{Fe}(\mathrm{OH})_{3(\mathrm{~s})}+3 \mathrm{NH}_{4}^{+}{ }_{(\mathrm{aq})}$ $\mathrm{Fe}(\mathrm{OH})_{3(\mathrm{~s})}+\mathrm{NH}_{4} \mathrm{OH}_{(\mathrm{aq})} \longrightarrow\left[\mathrm{Fe}(\mathrm{OH})_{4}\right]_{(\mathrm{aq})}^{-}+\mathrm{NH}_{4}{ }^{+}{ }_{(\mathrm{aq})}$

e. Reaksi dengan Udara dan tanah yang kaya dengan $\mathrm{S}^{2-}$

Padatan besi bereaksi dengan oksigen dan uap air menghasilkan karat atau besi hidrat

$$
4 \mathrm{Fe}_{(\mathrm{s})}+3 \mathrm{O}_{2(\mathrm{~g})}+\mathrm{x} \mathrm{H}_{2} \mathrm{O}_{(\mathrm{g})} \longrightarrow 2 \mathrm{Fe}_{2} \mathrm{O}_{3} \cdot \mathrm{xH}_{2} \mathrm{O}_{(\mathrm{s})}
$$

Besi(II) bereaksi dengan gas $\mathrm{H}_{2} \mathrm{~S}$ tidak membentuk endapan tetapi jika $\mathrm{S}$ berada dalam bentuk larutan dengan konsentrasi berlebih akan menghasilkan endapan hitam $\mathrm{FeS}$, $2 \mathrm{Fe}^{2+}{ }_{(\mathrm{aq})}+\mathrm{H}_{2} \mathrm{~S}_{(\mathrm{g})}+\mathrm{S}_{(\mathrm{g})}$ $2 \mathrm{FeS}_{(\mathrm{s})}+2 \mathrm{H}^{+}$ sedangkan besi(III) bereaksi dengan $\mathrm{H}_{2} \mathrm{~S}$ menghasilkan endapan berwarna putih dari sulfur.

$$
2 \mathrm{Fe}^{3+}{ }_{(\mathrm{aq})}+\mathrm{H}_{2} \mathrm{~S}_{(\mathrm{g})} \longrightarrow 2 \mathrm{Fe}^{2+}{ }_{(\mathrm{aq})}+2 \mathrm{H}^{+}{ }_{\text {(aq) }}+\mathrm{S}_{(\mathrm{s})}
$$

pada kondisi asam dan yang kaya dengan ion belerang, besi dapat membentuk endapan pirit atau $\mathrm{FeS}_{2}$

$$
\mathrm{Fe}^{2+}{ }_{(\mathrm{aq})}+2 \mathrm{~S}_{(\mathrm{aq})}^{-}+2 \mathrm{H}^{+}{ }_{(\mathrm{aq})} \longrightarrow \mathrm{FeS}_{2(\mathrm{aq})}+2 \mathrm{H}^{+}{ }_{(\mathrm{aq})}
$$

\subsection{Bentuk - bentuk mineral besi di alam}

Besi menempati urutan ke empat sebagai unsur yang paling melimpah $\mathrm{d}$ alam setelah oksigen, silikon dan aluminium (Fleischer, 1953). Unsur ini di alam tidak berada dalam keadaan murni namun bersenyawa dengan unsur lain menjadi mineral. Beberapa mineral yang merupakan bentuk senyawaan besi meliputi hematit $\left(\alpha \mathrm{Fe}_{2} \mathrm{O}_{3}\right)$, Mahemit $\left(\gamma \mathrm{Fe}_{2} \mathrm{O}_{3}\right)$, Magnetit $\left(\mathrm{Fe}_{3} \mathrm{O}_{4}\right)$, Ferrihidrit $\left(\mathrm{Fe}_{2} \mathrm{O}_{3} \times \mathrm{n}\right.$ $\left.\mathrm{H}_{2} \mathrm{O}\right)$, Geothit $(\alpha \mathrm{FeOOH})$, Lepidokrosit $(\gamma \mathrm{FeOOH})$, Ilemenit $\left(\mathrm{FeTiO}_{3}\right)$, Pyrit $\left(\mathrm{FeS}_{2}\right)$, Ferrosulfid $(\mathrm{FeS})$ dan Jarosit $\left(\mathrm{KFe}_{3}\left(\mathrm{SO}_{4}\right)_{2}(\mathrm{OH})_{6}\right)(\mathrm{US} \mathrm{EPA}, 2015)$

\section{Faktor Kenaikan pH Air dan Tanah terhadap Kelarutan Besi \\ 3.1. Kenaikan pH air}

Berdasarkan uraian sifat kimia besi diketahui bahwa besi membentuk endapan besi(II) hidroksida atau besi(III) hidroksida ketika bereaksi dengan basa. Dengan demikian, besi mengendap pada suasana basa. 


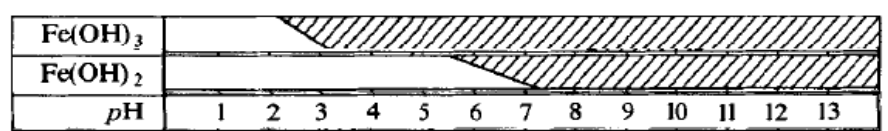

Gambar 1. Rentang pH pembentukan endapan besi hidroksida. Bagian terarsir menunjukkan terbentuknya endapan (Vogel \& Svehla, 1987).

Kenaikan nilai $\mathrm{pH}$ dari 1 hingga 13 mengindikasikan jumlah dan aktifitas ion $\mathrm{OH}^{-}$semakin bertambah. Hal ini menyebabkan interaksi ion besi dan hidroksida semakin tinggi sehingga jumlah endapan besi hidroksida semakin bertambah. Pembentukan endapan besi dengan kenaikan nilai $\mathrm{pH}$ dapat diamati pada Gambar 1

Nilai $\mathrm{pH}$ saat besi mulai mengendap diperoleh dari kajian nilai hasil kali kelarutan (Ksp). Nilai $\mathrm{Ksp} \mathrm{Fe}(\mathrm{OH})_{3}$ dan $\mathrm{Fe}(\mathrm{OH})_{2}$ pada tekanan konstan dan temperatur $25^{\circ} \mathrm{C}$ berturut-turut adalah $3,8 \times 10^{-38}$ dan $4,8 \times 10^{-16}$. Jika konsentrasi ion besi (III) sebanyak 0,01 M maka pada $\mathrm{pH} 2,19$ besi mulai mengendap sebagian dan seluruhnya akan mengendap pada pH 3 (Vogel \& Svehla, 1987).

\subsection{Kenaikan pH tanah}

Keasaman tanah adalah suatu kondisi di mana material - material penyusun tanah berkontribusi terhadap ionisasi $\mathrm{H}^{+}$dan $\mathrm{OH}^{-}$dengan hadirnya air dalam tanah. Derajat keasaman tanah atau $\mathrm{pH}$ tanah menurut Londo \& Kushla adalah ukuran aktifitas ion $\mathrm{H}^{+}$atau $\mathrm{OH}^{-}$dalam larutan air tanah, yang melembabkan atau merendam tanah. Tanaman dapat tumbuh pada tanah dengan rentang $\mathrm{pH}$ berkisar 3 - 9. Nilai $\mathrm{pH}$ asam atau basa dari tanah sama dengan nilai $\mathrm{pH}$ pada air, yaitu tanah asam dengan $\mathrm{pH} \leq 6,5$; tanah netral memiliki $\mathrm{pH} 6,5-7,5$; tanah basa dengan $\mathrm{pH} \geq 7,5$. Nilai $\mathrm{pH}$ tanah menentukan kandungan hara tanah bagi tumbuhan terutama unsur hara mikro (Londo \& Kushla, 2006).

Kelarutan dan pengendapan besi dalam tanah terjadi pada $\mathrm{pH}$ yang hampir sama dengan keberadaannya dalam air, yaitu besi larut pada $\mathrm{pH}$ asam dan mengendap pada $\mathrm{pH}$ basa. Namun, nilai $\mathrm{pH}$ kelarutan besi di dalam larutan tanah sedikit bergeser, yang mana besi masih larut pada $\mathrm{pH} 3$ dalam tanah, sedangkan besi dalam air sudah mengendap seluruhnya pada $\mathrm{pH} 3$ dengan kehadiran ion $\mathrm{OH}^{-}$. Besi larut dan tersedia berlimpah bagi tanaman pada $\mathrm{pH}$ tanah $3,0-5,9$ kerena tanah bersifat asam. Tanah dengan $\mathrm{pH}<4,5$ menyebabkan tanaman keracunan ion besi. Ion besi mulai mengendap pada $\mathrm{pH}$ 6,0 - 8,0 sehingga kandungan besi semakin kecil pada range $\mathrm{pH}$ tersebut. Peningkatan $\mathrm{pH} 4 \mathrm{ke} 8$ menyebabkan ketersediaan $\mathrm{Fe}^{3+}$ berkurang dengan jumlah yang larut sebanyak $10^{-8}$ menjadi $10^{-20} \mathrm{M}$ (US EPA, 2015). Besi mengendap seluruhnya di tanah pada $\mathrm{pH}>8,5$ membentuk $\mathrm{Fe}(\mathrm{OH})_{3}$ sehingga tidak dapat diserap oleh tanaman. Besi akan tersedia baik bagi tanaman pada range $\mathrm{pH} \mathrm{4,6-7,4}$ (Londo \& Kushla, 2006) sedangkan pada $\mathrm{pH} 7,5-8,5$ kelarutan $\mathrm{Fe}^{2+}$ sangat kecil yaitu mulai dari $10^{-10} \mathrm{M}$ (Colombo $\left.d k k ., 2014\right)$.

\section{Faktor Mikroorganisme dan Material Organik Tanah}

Bakteri menjadi mikroorganisme yang membantu melarutkan dan menyediakan besi bagi tanaman, dengan cara mereduksi besi atau menjadikan tanah asam. Reduksi besi(III) menjadi besi(II) dapat dimediasi oleh bakteri Shewanella putrefaciens (Ghorbanzadeh $d k k$., 2014). Bakteri Chryseobacterium C138 dapat mensuplai Fe untuk tanaman tomat (Radzki dkk., 2013). Thiobacillium and Metallogenium sp adalah Mikroba yang dapat melarutkan besi (Colombo dkk., 2014). Mikroba acidofilik khemolithotrof menurunkan $\mathrm{pH}$ tanah sehingga kelarutan besi dalam larutan tanah meningkat (Prijambada, 2014). Bakteri-bakteri lain yang dapat mengoksidasi besi adalah Ferrobacillus, Lepthrix, Gallionella dan Crenothrix (EPA, 2018)

Material organik tanah, hasil metabolisme bahan-bahan hayati, dapat mengikat besi. Asam-asam organik, sidepora, dan flavonoid mengikat besi dan menjadikan besi tersedia bagi tanaman (Colombo $d k k$., 2014). Pembentukan kelat oleh ligan organik membantu mobilitas ion besi di sekitar akar tanaman dalam tanah. Pengikatan ini terjadi karena material organik yang mengandung gugus - gugus seperti asam karboksilat, nitrogen, hidroksida, sulfat, fosfat yang dapat membentuk senyawa kompleks dengan besi. Material organik menjadi buffer bagi tanah, yang mana bahan ini akan melepaskan ion $\mathrm{H}^{+}$ketika $\mathrm{pH}$ tanah tinggi dan akan menarik ion $\mathrm{H}^{+}$dari tanah ketika $\mathrm{pH}$ tanah rendah. Material organik pada awal dekomposisinya akan meningkatkan $\mathrm{pH}$ tanah jika menghasilkan amoniak. Namun, amoniak yang dikonversi menjadi nitrat akan menurunkan $\mathrm{pH}$ tanah (McCauley $d k k$., 2009). Penurunan $\mathrm{pH}$ ini akan meningkatkan kandungan besi dalam tanah karena besi(III) akan tereduksi menjadi besi(II)

\section{Faktor pH dan Potensial Reduksi Lingkungan}

Banyak faktor yang mempengaruhi bioavalaibilitas besi bagi tumbuhan, seperti yang telah diuraikan pada bagian - bagian sebelumnya. Spesi besi di dalam tanah atau air berbeda jika dibandingkan dengan spesi besi di permukaan tanah atau air. Besi yang berada pada lapisan tanah atau air bagian dalam, dengan kehadiran material organik dan $\mathrm{pH}$ asam, akan mudah tereduksi dan membentuk $\mathrm{Fe}(\mathrm{II})$. Besi yang terletak pada permukaan air atau tanah dengan $\mathrm{pH}$ netral, mudah kontak dengan oksigen sehingga cenderung membentuk $\mathrm{Fe}(\mathrm{OH})_{3}$. Namun, faktor utama yang paling berpengaruh di lingkungan adalah potensial reduksi dan tingkat keasaman air atau tanah itu sendiri. Hal ini terjadi karena aktifitas bakteri, senyawa - senyawa kimia, udara, air dan reaksi-reaksi kimia di tanah menghasilkan total nilai potensial reduksi(E) dan $\mathrm{pH}$ tertentu. Spesi besi yang hadir pada $\mathrm{pH}$ dan nilai $\mathrm{E}$ tertentu dapat ditinjau menggunakan diagram pourbaix pada Gambar 2.
Korelasi atau Titik temu setiap nilai redoks dan $\mathrm{pH}$ dalam diagram pourbaix pada Gambar 2 menentukan spesi besi yang khas. Garis-garis dalam diagram tersebut menandakan batas terjadinya keseimbangan kimia antara spesi-spesi besi. Dua garis slop biru yang sejajar pada Gambar 2a menunjukkan batas kestabilan air, yang mana di luar garis biru bagian atas, dan bawah $\mathrm{H}_{2} \mathrm{O}$ terurai masing-masing menjadi $\mathrm{O}_{2}$ dan $\mathrm{H}_{2}$. Batas kestabilan air pada Gambar $2 \mathrm{~b}$ ditunjukkan dengan 2 garis slop merah sejajar, yang mana air juga akan terurai menjadi $\mathrm{O}_{2}$ dan $\mathrm{H}_{2}$ jika berada di luar garis tersebut. Garis vertikal, horizontal dan gradien garis masing - masing menandakan perubahan spesi besi bergantung hanya pada $\mathrm{pH}$, reaksi redoks (E) dan keduanya yaitu $\mathrm{pH}$ dan reaksi redoks (Delahay $d k k ., 1950)$.
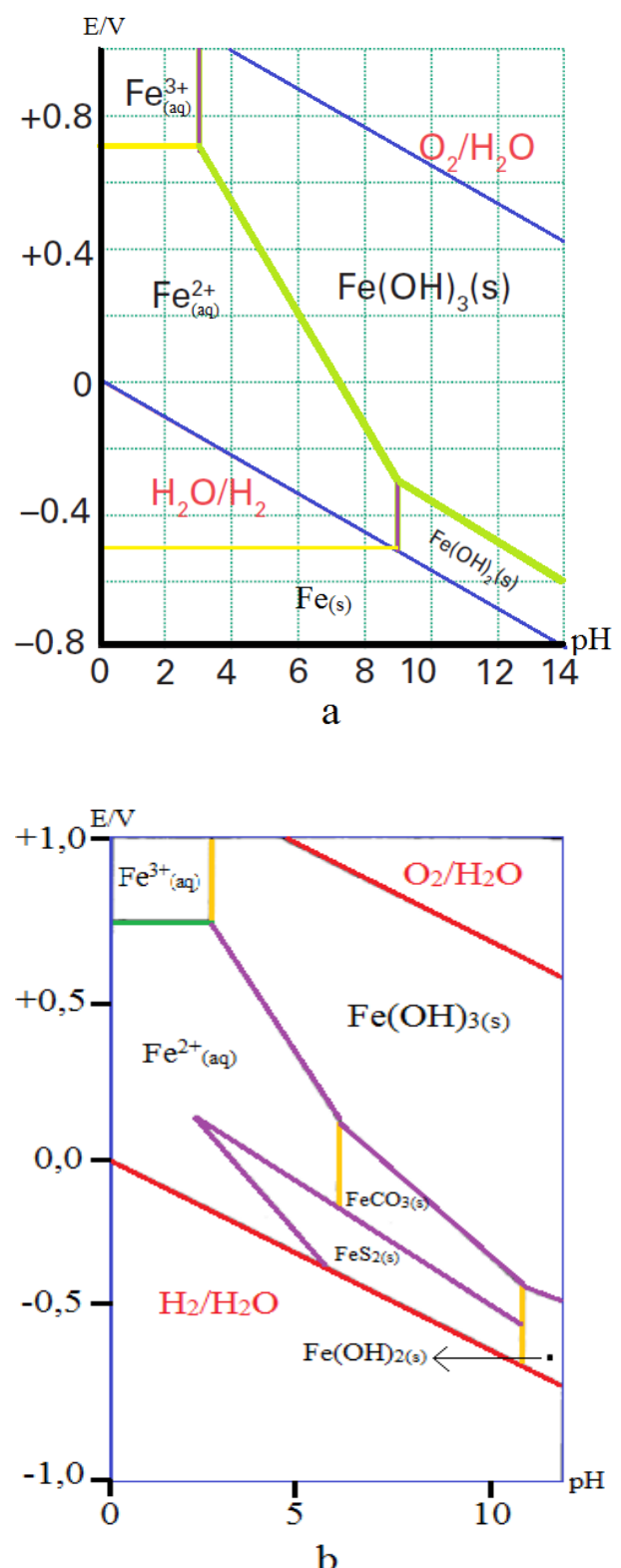

Gambar 2. Bentuk besi pada $\mathrm{pH}$ dan $\mathrm{E}$ berbeda di dalam :

a. air (Atkins \& Overton, 2010), b. tanah (US EPA, 2015).

Implementasi diagram pourbaix adalah untuk memprediksi kehadiran spesi besi di lingkungan. Aktifitas bakteri dan komponen non hayati di air atau tanah akan saling berkompetisi dalam menggunakan besi sehingga menghasilkan nilai reaksi redoks dan $\mathrm{pH}$ tertentu. Sebagai contoh, jika dalam air menghasilkan reaksi redoks $(\mathrm{E})<+0,4 \mathrm{~V}$ dan $\mathrm{pH} 4$, prediksi spesi besi harus menggunakan Gambar 2a, menampilkan bahwa relasi atau titik temu kedua nilai tersebut menunjukkan besi dalam bentuk ion $\mathrm{Fe}^{2+}$. Ion besi(III) dalam air akan berlimpah jika terjadi reaksi redoks sebesar $+0,8 \mathrm{~V}$ pada $\mathrm{pH} 3$. Endapan $\mathrm{Fe}(\mathrm{OH})_{3}$ dalam air akan terbentuk pada nilai redoks $+0,4 \mathrm{~V}$ dan $\mathrm{pH}$ 7. Prediksi pada tanah yang sedikit lembab dapat menggunakan Gambar $2 \mathrm{~b}$, yaitu jika E sebesar $0,5 \mathrm{~V}$ dan pH 4 maka besi berada dalam spesi $\mathrm{Fe}(\mathrm{OH})_{3}$. Kehadiran belerang di tanah pada pH 7 dengan $\mathrm{E}$ adalah $-0,25 \mathrm{~V}$ akan menghasilkan endapan $\mathrm{FeS}_{2}$. Kehadiran ion karbonat pada $\mathrm{pH} 8$ dan $\mathrm{E}$ sebesar $-0,1 \mathrm{~V}$ akan menghasilkan endapan $\mathrm{FeCO}_{3}$. Semakin tinggi kandungan air dalam tanah maka prediksi spesi yang dihasilkan akan lebih dominan mengikuti diagram pourbaix Fe di air (Gambar 2a), sebaliknya berkurangnya air dalam tanah dan jika terdapat ion $\mathrm{S}^{2-}$ dan $\mathrm{CO}_{3}{ }^{2-}$ maka spesi yang dihasilkan akan lebih dominan mengikuti diagram pourbaix $\mathrm{Fe}$ di tanah (Gambar 2b). 


\section{Simpulan}

Berdasarkan pembahasan dalam artikel ini maka dapat disimpulkan bahwa faktor - faktor yang mempengaruhi bioavailabilitas besi bagi tumbuhan adalah $\mathrm{pH}$, besarnya reaksi redoks, bakteri dan material organik tanah. Bioavailabilitas besi meningkat dengan reduksi besi oleh bakteri, pembentukan kelat oleh material organik tanah, semakin rendahnya nilai $\mathrm{pH}$ dan potensi reaksi redoks lingkungan yang disumbangkan oleh bakteri dan material organik tanah. Ketersediaan atau bioavailabilitas besi berkaitan dengan kelarutan besi, yang mana bertambahnya kelarutan besi maka semakin mudah diserap dan tersedia bagi tanaman. Nilai $\mathrm{pH}$ optimum penyerapan besi oleh tanaman yaitu pada $\mathrm{pH}$ 4,6 - 7,4. Besi akan menyebabkan tanaman keracunan akibat penyerapannya yang berlebih pada $\mathrm{pH}<4,5$. Defisiensi atau kekurangan besi bagi tanaman terjadi pada $\mathrm{pH}>7,5$ dan $\mathrm{pH}>8,5$ terjadi klorosis akut pada tanaman.

\section{Pustaka}

Atkins, P. \& Overton, T. 2010. Shriver and Atkins' Inorganic Chemistry. OUP Oxford.

Brown, J.C. 1956. Iron chlorosis. Annual Review of Plant Physiology, 7(1): 171190.

Calvert, J.B. 2003. "Iron" The metal of Mars gives us magnetism and life. [Edukasi] Iron. Tersedia di https://mysite.du.edu/ jcalvert/phys/iron.htm [Diakses 17 Juli 2018].

Colombo, C., Palumbo, G., He, J.-Z., Pinton, R. \& Cesco, S. 2014. Review on iron availability in soil: interaction of Fe minerals, plants, and microbes. Journal of Soils and Sediments, 14(3): 538-548.

Delahay, P., Pourbaix, M. \& Van Rysselberghe, P. 1950. Potential-pH diagrams. Journal of Chemical Education, 27(12): 683.

Fleischer, M. 1953. Recent Estimates in the Abundances of the Elements in the Earth's Crust. U.S. Government Printing Office.

Ghorbanzadeh, N., Lakzian, A., Haghnia, G.H. \& Karimi, A.R. 2014. Isolation and identification of ferric reducing bacteria and evaluation of their roles in iron availability in two calcareous soils. Eurasian soil science, 47(12): 1266-1273.

Hänsch, R. \& Mendel, R.R. 2009. Physiological functions of mineral micronutrients $(\mathrm{Cu}, \mathrm{Zn}, \mathrm{Mn}, \mathrm{Fe}, \mathrm{Ni}, \mathrm{Mo}, \mathrm{B}, \mathrm{Cl})$. Current opinion in plant biology, 12(3): 259-266.

Londo, A.J. \& Kushla, J.D. 2006. Soil pH and tree species suitability in the south. Southern Regional Extension Forestry, 2: 1-5.

McCauley, A., Jones, C. \& Jacobsen, J. 2009. Soil pH and organic matter. Nutrient management module, 8: 1-12.

Prijambada, I.D. 2014. Peran Mikroorganisme dalam Penyerapan Logam oleh Tanaman.

Radzki, W., Mañero, F.G., Algar, E., García, J.L., García-Villaraco, A. \& Solano, B.R. 2013. Bacterial siderophores efficiently provide iron to iron-starved tomato plants in hydroponics culture. Antonie Van Leeuwenhoek, 104(3): 321-330.

Rout, G.R. \& Sahoo, S. 2015. Role of iron in plant growth and metabolism. Reviews in Agricultural Science, 3: 1-24.

Seran, R. 2017. Pengaruh Mangan Sebagai Unsur Hara Mikro Esensial Terhadap Kesuburan Tanah dan Tanaman. BIO-EDU, 2(1): 13-14.

US EPA, O. 2015. Interim Ecological Soil Screening Level Documents for Iron. [Data and Tools] US EPA. Tersedia di https://www.epa.gov/chemicalresearch/interim-ecological-soil-screening-level-documents [Diakses 29 Juli 2018].

Vogel, A.I. \& Svehla, G. 1987. Textbook of Macro and Semimicro Qualitative Inorganic Analysis. Longman Scientific \& Technical. 